\title{
Polemika pomiędzy Piotrem Mohyłą a Kasjanem Sakowiczem wokół sprawowania sakramentu spowiedzi w cerkwi ruskiej (i unickiej) na podstawie utworów polemicznych ich autorstwa
}

\author{
ks. Andrzej Misiejuk \\ Katolicki Uniwersytet Lubelski \\ Polska \\ ORCID: 0000-0001-8802-8240 \\ andrijevic@wp.pl
}

rev. A. Misiejuk, The controversy between Peter Mohyla and Kassian Sakovych around the sacrament of confession in the Ruthenian (and Uniate) church on the basis of their polemical works, Elpis, 21 2019: 121-126.

\begin{abstract}
The article takes the arguments of the pastoral and theological polemics around the celebration of the sacrament of confession in the Orthodox Slavic traditions of the 17th century, based on the works of: "Lithos..." of metropolitan Peter Mohyla and „Perspectiwa...” of rev. Kassian Sakovych.

Streszczenie: Artykuł podejmuje argumenty teologiczno-pastoralnej polemiki wokół sprawowania sakramentu spowiedzi w prawosławnej słowiańskiej tradycji XVII wieku na podstawie dzieł: „Lithos...” metropolity Piotra Mohyły oraz „Perspectiwy...” księdza Kasjana Sakowicza.
\end{abstract}

Keywords: controversy, apology, the sacrament of confession, the sin, orthodox church

Słowa kluczowe: polemika, apologia, sakrament spowiedzi, grzech, cerkiew

\section{Wstęp}

To zdumiewające jak wiele prac i rozważań powstało na temat tego polemicznego pojedynku sprzed bez mała czterystu laty. Co zauważalne, odnosząc się do tej polemiki, autorzy w większości skupiają się na postaci metropolity Piotra Mohyły, którego pozycja, autorytet, twórczość, wkład w życie cerkwi i społeczności ruskiej ówczesnej Rzeczypospolitej są bezsprzeczne i niepodważalne (Łużny, 1996). Jego apologia w postaci „Lithosu...” (Mohyła, 1644) jest tego najlepszym dowodem. Osoba Kasjana Sakowicza, zdrajcy prawosławia, konwertyty i jak go nazywa Mohyła - podwójnego odstępcy, jawi się zaś jako dążący do konfrontacji krytyk rodzimego środowiska. Nie posiada z pewnością takiego autorytetu jak wstępujący z nim w pojedynek Mohyła. Biorąc pod uwagę oceny obu polemicznych utworów, można śmiało stwierdzić, że bez doskonałej, błyskotliwej odpowiedzi Mohyły na bolesną prowokację, krytyczne pisma Sakowicza nie zyskałyby aż takiego znaczenia, i co za tym idzie ani sama jego osoba, ani jego twórczość nie skupiałyby na sobie tyle uwagi (Olijnyk, 2012). Przy tak dużym zainteresowaniu spuścizną literacką metropolity Piotra Mohyły i jego adwersarza, analizy ich polemicznych tekstów okazują się jednak bardzo ogólnikowe i dość pobieżne (Kobylińska i Melnyk, 2017). Powód takiego stanu rzeczy jest prozaiczny - utwory te są stosunkowo obszerne, badacze bardziej skupiają się na całokształcie owych dzieł, formułując wynikające z nich ogólne wnioski. Dogłębna analiza poszczególnych elementów omawianych utworów wykracza daleko poza zainteresowanie, podstawową wiedzę czy też intuicję potencjalnego czytelnika, lecz z pewnością jest niezmiernie ważna i zarazem niezwykle ciekawa dla historyków, filologów, religioznawców i teologów. I jedynie pogłębiona analiza daje możliwość dokonania właściwej, obiektywnej oceny zawartych w pismach postulatów.

W swoich rozważaniach postanowiłem skupić się na jednym z zagadnień będących elementem składowym treści tychże polemicznych utworów. W polemicznej batalii na front rzucone zostały sakramenty - ich istota, forma, materia, znaczenie i wreszcie błędy, nadużycia w sposobie ich sprawowania. Sakramenty, jako przejaw życia kościelnego, stanowią w rzeczy samej doskonały probierz stanu świadomości, duchowej formacji duchowieństwa i wiernych. Spośród wszystkich sakramentów wybrałem sakrament spowiedzi - z punktu widzenia teologa i duchownego to bowiem bardzo istotny element religijności, dający możliwość obiektywnej oceny stanu dogmatycznej, liturgicznej i duchowej kondycji ówczesnej cerkwi wschodniej.

\section{Zarzuty K. Sakowicza}

Na podstawie zawartych w „Perspektiwie...” Sakowicza zarzutów można dokonać próby oceny ówczesnego 
obrazu życia religijnego cerkwi prawosławnej (Sakowicz, 1642). Pamiętać wszakże należy o całej złożoności sytuacji w jakiej znalazła się w tym czasie cerkiew, jej pasterze i wierni - prawosławni mieszkańcy Rzeczypospolitej (Naumow, 1996).

Przyjrzyjmy się więc Kasjanowym zastrzeżeniom odnośnie sprawowania sakramentu spowiedzi - „W sakramencie pokuty nieprzystojnościom". W pierwszej części tekstu dotyczącego sakramentu spowiedzi zatytułowanego „o inconvenientiach w sacramencie pokuty” autor wylicza wydaje się najpoważniejsze grzechy duchowieństwa kościoła wschodniego ${ }^{1}$. Co warto zauważyć, autor swej krytyki nie odnosi do wiernych, na odwrót - niejako bierze ich w obronę, traktując ich jako bezwolne ofiary niewykształconego oraz pozbawionego przyzwoitości i moralności kleru. Poniższa analiza dokonana została według porządku ukazanego w Regestrze - „Regestr Abo summaryusz rzeczy w tych książkach zamykających się, dla prędszey wiadomości y znalezienia Czytelnikowi krótko napisany" (Sakowicz, 1642, fol. 6-11). Poszczególne paragrafy otrzymały oryginalne tytuły zapisane w utworze Sakowicza.

1.1. „Ruscy popi rzadko się spowiadają” (Sakowicz, 1642, fol. 6-7)

Zawarty jest tu zarzut dotyczący dyscypliny, a nawet samodyscypliny kapłańskiej. Rzadkie przystępowanie do spowiedzi, za wyjątkiem odbywającej się co kilka lat spowiedzi na rekolekcjach zarządzanych przez biskupa, odprawianie liturgii bez należytego przygotowania, nieprzestrzeganie dyscypliny m.in. picie alkoholu w noc poprzedzającą odprawianie liturgii, nieznajomość kanonów dotyczących spowiedzi.

1.2. „Pop każdy ze wszystkich grzechów rozgrzesza” (Sakowicz, 1642, fol.7-8)

Sakowicz zarzuca tu brak elementarnej wiedzy dotyczącej nauczania o grzechu, rozróżnienia poszczególnych grzechów, ich kategorii, a przede wszystkim zakresu kompetencji spowiednika - sugeruje, że rozgrzeszenie z określonych, najcięższych grzechów zarezerwowane powinno być władzy biskupiej, czy wręcz stolicy Apostolskiej. Taka praktyka wydaje się mu zdolna zapobiegać popełnianiu ciężkich przewinień. Niestosowanie się do niej prowadzi zaś do nadużyć i zgorszenia wiernych, którzy jak udowadnia, niekiedy wręcz przemocą wymuszają udzielanie sobie rozgrzeszenia.

1.3. „Formy rozgrzeszenia schizmatyccy popi nie mają" (Sakowicz, 1642, fol.8)

W odróżnieniu od obligatoryjnej formuły rozgrzeszania zmarłych „rozgrzeszam albo rozwiązuję cię ja synu mój duchowny i żebyś był rozwiązany i na niebie", stosowanej nawet wobec tych, którzy i za życia się nie spowiadali, autor twierdzi, że duchowni nie znają sakramentalnej formuły rozgrzeszenia dla spowiadających się żyjących. Spowiednicy wypowiadają bowiem wobec nich tylko sło-

\footnotetext{
„Perspektiwa...”wymierzona jest również przeciwko duchowieństwu kościoła unickiego, który według K.S zbytnio związany pozostaje z pełną błędów, zabobonów i herezji obrzędowością i tradycją schizmatyckiej cerkwi prawosławnej.
}

wa „Boh tia prostit”, które mają mniejszą wagę niż wyżej wymieniona formuła stosowana wobec zmarłych.

1.4. „Umarłych rozgrzeszają i listy umarłym do św. Piotra dają" (Sakowicz, 1642, fol.8-9)

Za niedopuszczalne nadużycie uważa jakoby spotykaną w wielu miejscach praktykę wkładania do rąk nieboszczyków listów do św. Piotra, aby zmarłym „wrota do nieba otworzył". Jak pisze - podobne listy, jeszcze za życia, niektórzy kupują za pieniądze u hierarchów cerkiewnych. Na przytoczone schizmatyckie (t.j. prawosławne) argumenty twierdzące, iż jeśli rozgrzeszyć zmarłego nie wolno tak też i nie wolno modlić się za niego po śmierci odpowiada, że „w modlitwach jest prośba, a w rozgrzeszeniu władza".

1.5. „Okoliczności grzechów niewiedzą i stanów spowiadających się nie uważają" (Sakowicz, 1642, fol.9)

Autor krytykuje powszechną nieznajomość listy grzechów, ich klasyfikacji i gradacji. Zarzuca duchownym to, że nie uczą i nie wymagają od spowiadających się restytucji, zadośćuczynienia za wyrządzone krzywdy materialne bądź naruszenie czyjejś godności osobistej. Kwestionuje też brak odpowiedniego stosunku do spowiadających się ze względu na zajmowany przez nich stan (!) i okoliczności popełnienia grzechu.

1.6. „Osadzonych na śmierć wątpią aby byli zbawieni” (Sakowicz, 1642, fol.9-10)

Kolejny zarzut Sakowicza wymierzony jest $\mathrm{w}$ licznych duchownych, którzy z urzędu („dekretu”) skazanych wyrokiem sądowym na śmierć uważają za pozbawionych możliwości zbawienia, nawet w przypadku spowiedzi i autentycznej skruchy za popełnione grzechy. Według autora sprzeczne jest to z przykładem danym przez samego Chrystusa, który żałującego łotra skruchę przyjmuje. Dobitny przykład tego stanu rzeczy przytacza autor twierdząc że „takiej rozpaczy nauczał schizmatycki pop z Ostroga”, który już nie żyje (,zdechł”).

1.7. „Grzechów nieznajomych na spowiedziach nauczają" (Sakowicz, 1642, fol.10)

Zgorszeniem dla nieświadomych, uczciwych wiernych, jest wymienianie przy spowiedzi grzechów „szkaradnych", czy też nakaz powtarzania za spowiednikiem grzechów, których nie popełnili, i o których nigdy nie słyszeli. Przez to stają się one w opinii autora powodem zgorszenia i uczą grzeszenia. Podobny skutek mają niektóre z odmawianych modlitw.

1.8. „Do przysięgi na spowiedzi przywodzą aby do unii albo Kościoła Rzymskiego nie przystawali" (Sakowicz, 1642, fol.10)

Sakowicz zarzuca schizmatyckim duchownym wykorzystywanie spowiedzi do zmuszania spowiadających się do składania przysięgi o pozostaniu przy swojej wierze nie przechodzenie na rzymski katolicyzm lub unię.

1.9. „Objawiają drudzy spowiedź i jawno grzeszników czasem publikują", ,jawnie z grzechów strofują i za jawno grzeszników publikują"2 (Sakowicz, 1642, fol.10)

\footnotetext{
2 Uzupełnienie tytułu z Regestru o zapisany na marginesie tekstu w treści paragrafu, folio 10 .
} 
Autor krytykuje tu duchownych za ujawnianie tajemnicy spowiedzi. Potępia przypadki wyjawiania tajemnicy spowiedzi sług ich panom, jak też swym żonom. Mówi o przypadkach publicznego napiętnowania spowiadających się wiernych poprzez niedopuszczanie ich do komunii określając ich słowami niegodny/niegodna. W dowód tego przytacza przykład pewnej pobożnej osoby z Krzemieńca na Wołyniu, która w taki sposób zawstydzona przechodzi zaraz do kościoła rzymskiego.

\section{Błędy w sposobie sprawowania sakramentu spowiedzi}

W drugiej części zarzutów Sakowicza wobec sprawowania spowiedzi zatytułowanych „O sposobach słuchania spowiedzi. Rozmaite sposoby słuchania spowiedzi u schizmatyków, ba i niektórych unickich popów" autor stara się wytknąc rażące błędy w samym sposobie sprawowania sakramentu (Sakowicz, 1642, fol.10-11).

2.1. „Słuchanie spowiedzi prywatne albo w cerkwi drzwi zawarłszy, albo w celi sam z samym, albo samą zostawszy" (Sakowicz, 1642, fol.11)

Z trwogą i obawą, przede wszystkim o spowiadające się białogłowy, występuje Sakowicz przeciw praktyce spowiedzi sam na sam, przy zamkniętych drzwiach świątyni. Podczas gdy inni spowiednicy stoją na zewnątrz, w trakcie spowiedzi może dochodzić do niewłaściwych sytuacji, o co posądza „nie starych jeszcze kapłanów... wie go zły Duch co tam czasem bywa za spowiedź".

2.2. „Spowiadając i pop stoi i penitencjarz” (Sakowicz, 1642, fol.11)

W jednym zdaniu stwierdza, iż (w odróżnieniu od łacińskiej formy spowiedzi) duchowny i spowiadająca się osoba stoją, zaś na stoliku przed nimi ma leżeć Ewangelia, która ma jakoby przypominać, aby do grzechów popełnionych nie wracać.

2.3. „Wielu razem drudzy popi spowiadają” (Sakowicz, 1642, fol.11)

W tym miejscu autor mówi o praktyce spowiedzi powszechnej (ogólnej) sprawowanej nad zebraną w świątyni grupą dzieci, wyrostków czy nastolatków. Po przeczytaniu nad nimi modlitwy rozgrzeszającej duchowni rozpuszczając ich mają pytać, czy ktoś z nich czuje się winien $w$ jakimś grzechu. Jeśliby takowe były, mają pozostać, bądź przyjść ponownie, co wydaje się autorowi absurdem, bowiem nikt, z uwagi na wstyd wynikający z ujawnienia grzechów, do duchownego już nie przyjdzie.

2.4. ,Zadawaniem wielkich pokut do rozpaczy przywodzą" (Sakowicz, 1642, fol.11)

W ostatnim już punkcie zarzuca duchownym zadawanie ,wielkich i nieznośnych pokut”, które na kilka lat pozbawiają możliwości spowiadania się i przystępowania do sakramentu eucharystii. Wielka liczba postów i pokłonów sprawia, że wierni doprowadzani są do rozpaczy, inni natomiast świadomi „wymiaru pokuty” odstępować mają nawet od przystępowania do spowiedzi.

\section{Apologia metropolity Piotra i obrona prawosławnej praktyki liturgicznej}

Tyle w kwestii Kasjanowych zarzutów dotyczących sakramentu spowiedzi zawartych w „Perspektiwie...”, na którą pod pseudonimem ojca Euzebia Pimina odpowiedzieć postanawia metropolita Piotr Mohyła (Sachariewa, 2014). Wcześniej w 1640 roku temat dyscypliny cerkiewnej i niezbędnych reform liturgicznych podjęty zostaje na Soborze w Kijowie, którego przebieg i prace z uwagą i właściwą sobie uszczypliwością relacjonuje ks. Kasjan Sakowicz (Sakowicz, 1642a). Wreszcie w 1644 r. drukiem ukazuje się „Lithos czyli kamień z procy...”, który stanowi bezpośrednią odpowiedź na zarzuty postawione w Kasjanowej „Perspektiwie...”’. Wartym podkreślenia jest też sam fakt, że omawiane tu polemiczne dzieła napisane zostały w języku polskim (Romanowski, 2018).

Apologia Piotra Mohyly w postaci antytez do krytyki i oskarżeń Kasjana Sakowicza to prawdziwy traktat teologiczny (Łużny, 1996). W jego obszernej treści znalazły się też odpowiedzi na postawione zarzuty dotyczące sakramentu spowiedzi - „Na fałszywie wyliczone Inconvenientia w Sakramencie Pokuty odpowiedź. Na fałszywie wyliczone rozmaite sposoby słuchania Spowiedzi odpowiedź. O Sakramencie Spowiedzi”(Mohyła, 1644, s. 33-48). Prześledźmy, krok po kroku, argumenty po jakie sięga Mohyła.

Za potwarz uważa niepoparty żadnymi dowodami (pisemnymi lub bezpośrednimi) fałszywy zarzut dotyczący rzadkiej spowiedzi duchownych (Mohyła, 1644, s. 33-34). Zaznacza, że o podobnej praktyce nie może być mowy w Trebniku. Dowodzi, że duchowni świadomi są dyscypliny cerkiewnej, uczą tego bowiem młodych kapłanów, mają swoich spowiedników i często przystępują do spowiedzi - łaźni duchowej, tak przed sprawowaniem liturgii, jak też 12 razy w roku oprócz przypadków szczególnych. Również wiernych przyuczają do tego, aby należycie przygotowawszy się przystępowali czterokrotnie do spowiedzi i stołu Pańskiego. Jeżeli takie nadużycia mają miejsce to $\mathrm{z}$ pewnością dotyczą duchownych w kościele unickim, do którego z racji chęci zachowania majętności niektórzy przystali. Mohyła kpi, iż wyrzuty sumienia z tego właśnie powodu, nie pozwalają przystępować im do spowiedzi. W kwestii zarzutu dotyczącego spożywania alkoholu przypomina o postawie samego Sakowicza, który w Łucku, Ostrogu i Dubnie sam miał oddawać się pijaństwu.

Na kolejny zarzut, dotyczący braku umiejętności spowiadania się i słuchania spowiedzi oraz nierozróżniania między grzechami śmiertelnymi i nieśmiertelnymi, stwier-

Za Z. M. Kobylińską i M. Melnykiem (Kobylińska i Melnyk, 2017) warto odnotować, iż na „Perspektiwę...” Sakowicza odpowiedzieli też przedstawiciele cerkwi unickiej: Pachomiusz Wojna Orański (Zwierciadto albo zasłona... naprzeciw uszczypliwej Perspektywie, Wilno 1645), Jan Dubowicz (Obraz prawosławnej Cerkwi Wschodniey, Lwów 1645), Cyryl Trankwilion Stawrowiecki (Obraz prawosławnej cerkwi wschodniej, Kijów 1646). 
dza, że sytuacja taka jest możliwa, a wynika z pięćdziesięcioletnich prześladowań ze strony unitów i braku swych pasterzy (Mohyła, 1644, s. 35). Ripostując powołuje się na podobne temu znane przypadki w kościele zachodnim, stwierdzając przy tym, że nie wpływa to na ważność sprawowanego sakramentu.

Na zarzut o nieposiadanie ksiąg kanonnych, przypomina (byłemu przecież duchownemu prawosławnemu) o Nomokanonie traktującym o ludzkich grzechach, epitemiach itd. (Mohyła, 1644, s. 35-36). Przeciwstawia go zachodnim tekstom Antonini Diana, Panormitani Clerici Regularis (Antwerpia 1635), twierdząc, że Ruś woli się „staroświeckich Nomokanonów trzymać”.

Oskarżenia o praktykowanie rozgrzeszania z grzechów podlegających władzy biskupiej potwierdza tłumacząc ponownie, iż było to wynikiem pięćdziesięciu lat prześladowań i faktycznego braku biskupów (Mohyła, 1644, s. 36). Wskazuje, że winowajczynią takiego stanu rzeczy jest unia, natomiast $\mathrm{w}$ obecnej chwili nie ma podstaw do obwiniania biskupów, którzy ,już tego nauczają i znowu w nich (duchownych) to wpajają". W odniesieniu do krytyki rozgrzeszania zmarłych Mohyła stwierdza, że takiej modlitwy rozgrzeszającej nie zawiera Trzebnik grecki, ani wiele Trebników słowiańskich (Mohyła, 1644, s. 36-37). Zgadza się, że nie jest ona właściwą (,nic tam po niej”) i zarazem wyjaśnia, że intencją Trebników, w których modlitwa takowa występuje, jest nie rozgrzeszanie zmarłych, co jest niedopuszczalne, lecz oznajmienie wszystkim uczestniczącym w pogrzebie, iż nieboszczyk jak przystało chrześcijaninowi, umarł w pokucie. Dodaje, że do nowego Trebnika, skorygowanego na podstawie Trebnika greckiego formuły rozgrzeszenia nie włączono, o czym duchowni doskonale wiedzą. Rozgrzeszenie zmarłemu może udzielić tylko biskup, w Trebniku są stosowne modlitwy na takie okoliczności. Następnie szeroko opisuje przypadki potwierdzające skutki śmierci wyklętych bez rozgrzeszeniaich ciała nie rozkładają się (powołuje się tu na „Historiam turcograecicam", oraz opisuje przypadek mający miejsce w Wilnie w 1635 r.), zaś rozgrzeszenie biskupie sprawia, że ciało obraca się w proch, co jest potwierdzeniem świętości cerkwi i jej mocy wiązania i rozwiązywania.

W odpowiedzi na twierdzenia, iż nieboszczykom wkładane są listy pisane do św. Piotra, Mohyła stwierdza, że czegoś podobnego nie ma ani w Trebnikach, ani w zwyczaju cerkiewnym, toteż tego rodzaju praktyka nie ma miejsca u duchowieństwa prawosławnego (Mohyła, 1644, s. 38). Dodaje zarazem, że takie nowości występują w cerkwi unickiej, więc na podobne zarzuty to oni winni odpowiadać. Przy okazji wspomina o praktyce Kościoła Rzymskiego kiedy chowając biskupa kładziono mu na pierś prosforę albo oblatę (powołuje się tu na tekst ex Beda Amalarius).

W kolejnym punkcie autor odrzuca oskarżenie Sakowicza o nieznajomość liczby grzechów, w szczególności śmiertelnych - ironicznie stwierdza, że gotów się jest założyć, że i on sam nie może znać pełnej liczby grzechów, tak jak ich liczby nie sposób określić (Mohyła, 1644, s. 39).

Na oskarżenie o nie nauczanie restytucji, konieczności zwracania cudzych rzeczy i zadośćuczynienia mówi o po- zbawionej dowodów uszczypliwości, jednak potępia tych, którzy mieli tak czynić (Mohyła, 1644, s. 39).

W odniesieniu do zarzutu, iż kwestionuje się możliwość zbawienia (czyli zasadność rozgrzeszenia) w stosunku do osądzonych na śmierć, ale żałujących za grzechy i pragnących się spowiadać Mohyła, ze szczególną dozą ironii (,o niewstydliwy kłamco!”), stwierdza, że więcej jest tych, którzy z większymi grzechami potajemnie przystępują do spowiedzi i uzyskują rozgrzeszenie, aniżeli osądzonych na śmierć, ze skruchą żałujących za grzechy i obiecujących więcej ich nie popełniać. Tak więc nie wątpiąc w możliwość ich zbawienia, wyznaczywszy należytą pokutę, kapłani udzielają im rozgrzeszenia. Szydzi ze swego oponenta stwierdzając, że „takiej nauki” nie mógł wyczytać ani w Trebnikach, ani w innych księgach cerkiewnych, chyba że „u arendarza Dubienskiego, w Żydowskim Talmucie, albo w Ostrogu u Tatarskiego Mołły w Alkoranie..." (Mohyła, 1644, s. 39-40).

Obwinienia o zmuszanie do powtarzania podczas spowiedzi grzechów, których spowiadający się nie popełnił i o nich nie słyszał, oddala twierdząc, że duchowni opierając się na wskazówkach swoich pasterzy, dawnych rękopiśmiennych jak i nowych drukowanych Nomokanonach i Trebnikach, wiedzą jak powinna wyglądać spowiedź, nawet najprostszych nieumiejących spowiadać się wiernych (Mohyła, 1644, s. 40-41). Nie pytają o grzechy i okoliczności, które mogłyby prowadzić do zgorszenia i poznania nieznanych dotąd grzechów. W dalszej części metropolita zauważa, że również nowowydany moskiewski Trebnik (pag.171) oraz Nomokanon zawiera odpowiednie wskazówki dotyczące właściwego przeprowadzenia spowiedzi, jak i o co należy pytać spowiadających się „najroztropniej wybadywać... i najprzystojniej pytać... aby doskonała była".

O zmuszaniu podczas spowiedzi do złożenia przysięgi, że od Schizmy do Kościoła Rzymskiego albo unii nie przystąpią Mohyła przypomina Sakowiczowi, iż jest on nie tylko schizmatykiem, ale i apostatą - nie tylko od wiary prawosławnej do unii, ale i z unii do drugiego rytu przeszedł, habit i śluby monastyczne porzucił składając przy tym przysięgę, że do unii nigdy nie powróci, co potwierdza własnoręcznie napisany list do archimandryty Dubienskiego Chmielewskiego. Wypominając Sakowiczowi jego „grzechy” zaznacza, że podobnego postępowania w odniesieniu do tych, którzy o odstąpieniu od wiary nie myślą i nie wątpią, nie było i nie ma (Mohyła, 1644, s. 41).

W odniesieniu do rzekomego wyjawiania Panom tajemnicy spowiedzi ich sług twierdzi, iż nie zna takich przypadków, bowiem nie zostały przedstawione na to dowody, jednakże jeśliby i ktoś tak postąpił, powinien być publicznie potępiony (Mohyła, 1644, s. 41-42). Ze względu na odosobniony przypadek, ,jednego zbrodnią tobie podobnego" Cerkiew Chrystusowa nie może za to ponosić odpowiedzialności (,nagany”). To Sakowicza obarcza o wyjawianie znanych ze spowiedzi przewinień Unitów poprzez upublicznienie ich w wydanych przez siebie drukiem pismach, konstatując, że z pewnością w tej kwestii musi dręczyć go sumienie. 
Co do przypadku, popartym przykładem mającym miejsce na Wołyniu, jakoby któryś z duchownych miał nie dopuszczać do komunii, nazywając kogoś niegodnym/ niegodną, wyrokuje że musi chodzić tu o umyślnie podmówienie i przekupstwo pozbawionego sumienia duchownego, by w taki sposób odwieść od swej wiary stateczną osobę, gdy nie ma na to innej metody (Mohyła, 1644, s. 42).

W drugim rozdziale zatytułowanym „Na fałszywie wyliczone rozmaite sposoby słuchania Spowiedzi Odpowiedź. O Sakramencie Spowiedzi” (Mohyła, 1644, s. 43) już na wstępie, z ironią (,a wżdyć durniu”), poucza Sakowicza, że jest Sakrament Pokuty a nie spowiedzi, bowiem spowiedź jest jedną z trzech części sakramentu.

Następnie, zgodnie z chronologią zawartą w „Perspectiwie ...", ustosunkowuje się do oskarżeń o gorszącą praktykę spowiedzi sam na sam, przy zamkniętych drzwiach świątyni (Mohyła, 1644, s. 43-44). Obwinia Sakowicza o bezwstydne pomówienia pełne sprośności i kłamstwa. Upatrując taką postawę w odrzuceniu przezeń wstydu charakterystycznego skromności zakonnej, wyrzuca mu, że postawione oskarżenia nie mają żadnego uzasadnienia w Trebniku, i o żadnych nieprzystojnościach, z których ośmiela się drwić nigdy nie słyszano. Dalej przechodzi do ujawnienia niechlubnych epizodów z życia samego Sakowicza. Zgodnie z przytoczonymi faktami podczas, gdy ten był diakonem w katedralnej cerkwi św. Jana w Przemyślu miał zabić mężczyznę, jaki nakrył go podczas ,spowiadania" jego żony. Tylko dzięki ślubom zakonnym w Kijowie miała go ominąć kara śmierci. Następnie przywołuje niechlubne praktyki spowiadania zakonnic w Monasterze Św. Krzyża w Dubnie, czy też pewnej Pani w monasterskim folwarku w Miatynie.

W odpowiedzi na kolejny zarzut, dotyczący spowiedzi sprawowanej na stojąco, wyjaśnia iż zarówno w Grecji jak i tu stosuje się obie formy - duchowny siedzi bądź stoi (Mohyła, 1644, s. 44-45). Nie popełnia żadnego błędu duchowny kiedy spowiada stojąc przed ołtarzem [dla większego uszanowania Najświętszego Sakramentu na Ołtarzu będącego], ani też ten, który [jako sędzia siedzi]. Towarzysząca spowiedzi Ewangelia, nie jest dla przysięgi, do której spowiadających się żaden kapłan nie zmusza, lecz ma przypominać o powadze sprawowanego sakramentu oraz świadomości niewidzialnej obecności samego Zbawiciela Chrystusa, przed którym z bojaźnią, strachem i skruchą się spowiada. Argumentuje powyższe tym, iż księga Ewangelii towarzyszy wszystkim innym sakramentom, Soborom, czy innym zgromadzeniom biskupim lub kapłańskim.

W następnym punkcie Mohyła oddala oskarżenia o spowiadanie na osobności w celach zakonnych (Mohyła, 1644, s. 45). Nie ma wg niego takiego zwyczaju ani w cerkwiach monasterskich, ani parafialnych (,świeckich") i spowiedź wszystkich, w tej mierze białych głów, odbywa się tylko w cerkwi.

W odpowiedzi na zarzut praktykowania spowiedzi ogólnej nad wyrostkami, stwierdza, że jest to powszechne u unitów na Litwie i dotyczyć ma również dorosłych (Mohyła, 1644, s. 45-46). Nie ma jednak o tym mowy w Trebniku i takiej praktyki się nie stosuje u prawosławnych.
W ostatnim, obszernym fragmencie Mohyła ustosunkowuje się do obwinień odnoszących zadawania pokuty, która na kilka lat pozbawia możliwości spowiadania się i przystępowania do sakramentu eucharystii (Mohyła, 1644, s. 46-47). Kłamstwem nazywa twierdzenie, iż rodzajem pokuty jest zakaz przystępowania do spowiedzi - przeciwnie, ciężej grzeszący powinni częściej przystępować do spowiedzi, by w ten sposób wyzwolić się z popełnionych grzechów. W kwestii zadawania w ramach pokuty wielu postów, pokłonów, nie zważając na wiek lub stan wiernych, przypomina, że nie ma stanów wolnych od pokuty. Podkreśla, że w odniesieniu do pokuty, prawosławnym bliższa jest praktyka trzymania się środka. Zauważa, iż mała pokuta nie przynosi wiele pożytku i wręcz prowadzi do zepsucia życia chrześcijańskiego. Co do krytykowanej praktyki czasowego odłączenia od eucharystii przypomina o regulujących ją kanonach św. Bazylego Wielkiego i św. Jana Postnika. Twierdzi, że posty, modlitwy, jałmużny, włosiennice i twarde łoża są przez wszystkich kanonistów uważane za pożyteczne i zbawienne. Zaręcza, że duchowni doskonale zdają sobie sprawę jaką, stosownie do wieku, stanu zdrowia, pozycji społecznej, należy wyznaczać pokutę. Wskazuje przy tym na Nomokanon, ale też łacińskie Agendy, dając do zrozumienia, że również w tradycji rzymskiej nie ,jednym paciorkiem... większy grzech pozbyć trzeba". Powołuje się też na Sobór w Ancyrze oraz kanony św. Bazylego Wielkiego. Przytacza w tym miejscu i szczegółowo omawia 59 kanon określający pokutę za cudzołóstwo. Następnie wskazuje na słowa ks. Piotra Skargi (kazanie zaduszne, cz. II p. 651) dowodząc, iż nie tylko cerkiew wschodnia, ale i kościół „kiedyś takie pokuty zadawał”. W podsumowaniu stwierdza, że ostrość w kwestii pokuty za grzechy ma na celu zasianie strachu przed grzechami, tak by ich nie lekceważyć i nie wpadać w cięższe przewinienia. Zadośćuczynienie, cierpliwe trudy sprawią zaś, że wierni staną się czujniejsi i ostrożniejsi, a pokornie przyjęta pokuta ustrzeże ich przed zasłużoną karą. W ostatnich zdaniach Mohyła drwi z Sakowicza pytając o to, czy aby zbytnim folgowaniem nie oziębili miłości chrześcijańskiej, czy nie przyczynili się do pomnożenia grzechów. Kwituje to słowami ,jak łatwe rozgrzeszenie, tak prędkie do grzechów wracanie się" i pyta jak wielu udało się nawrócić arian, heretyków, czy aby nie przez indulgencje zginęły (dla Kościoła rzymskiego) takie państwa jak Anglia, Szkocja, Szwecja, Niderlandy.

\section{Zakończenie}

Powyższe zestawienie zarzutów Sakowicza dotyczących sakramentu spowiedzi i odpowiedzi na nie Mohyły pozwala w syntetyczny sposób zilustrować obraz ówczesnych, międzykonfesyjnych relacji, faktyczny stan teologicznej wiedzy i religijnej świadomości duchowieństwa i po części samych wiernych. Analiza poszczególnych, zawartych w polemice oskarżeń, wyjaśnień, twierdzeń i postulatów jest pomocna w dokonaniu obiektywnej oceny 
stanu dogmatycznej, liturgicznej i duchowej kondycji ówczesnej cerkwi wschodniej. Dowodzi ona z jednej strony autentycznych problemów z jakimi borykała się prześladowana i spychana na margines życia cerkiew prawosławna, z drugiej zaś niezwykłego ducha walki o przetrwanie oraz przekonania o ogromnym bogactwie tkwiącym $\mathrm{w}$ duchowej spuściźnie cerkwi prawosławnej (Gołubiew, 1898).
Odpowiedź na zarzuty Sakowicza jest w dużej mierze zapowiedzią, przygotowywanej przez środowisko reprezentowane Mohyłą, liturgicznej reformy, kodyfikacji tekstów liturgicznych, korekty i redakcji ksiąg cerkiewnych, która znalazła swoje zwieńczenie w postaci wydanego tuż przed samą śmiercią metropolity w 1646 r. „Wielkiego Trebnika” (Nowakowski, 2004).

\section{Bibliografia}

Gołubiew, S. (1898). Kijewskij mitropolit Piotr Mogiła i jego spodwiżniki. Kijów: Drukarnia S.W. Kulżenko (t. 2).

Karpluk, M. (1998). Ku dalekiemu pojednaniu. Dysputa prawosławno-katolicka metropolity Piotra Mohyły z ks. Kasjanem Sakowiczem. W: Z. Leszczyński (red.) Czterechsetlecie unii brzeskiej. Zagadnienia języka religijnego (s. 37-47). Lublin: Wydawnictwo KUL.

Kobylińska, Z. M., Melnyk, M. (2017). Edycja i opracowanie naukowe pism polemicznych Kasjana Sakowicza i Piotra Mohyły. Problem badawczy. Seminare. Poszukiwania naukowe (t. 38, nr 1, s. 151-163). Kraków-Piła-Warszawa -Wrocław: TNFS.

Łużny, R. (1996). Metropolita Piotr Mohyła: człowiek dialogu na pograniczu kulturowym grecko-słowiańskim i łacińsko-polskim. W: Acta Polono-Ruthenica 1, s. 333-348, Olsztyn.

Mohyła, P. (1644). Lithos abo kamień z procy prawdy cerkwie świętej prawosławnej ruskiej na skruszenie fałeczno ciemnej Perspektiwy albo raczey Paszkwilu od Kassiana Sakowicza, bytego przedtym Kedyś Archimandritę Dubieńskiego Unita, iakoby o błędach, Herezyach, y Zabobonach Cerkwie Ruskiey w Uniey nie będacey, tak w Artikułach wiary, iako w Administrowaniu Sakramentow y inszych obrzadkach y Ceremoniach znayduiacych się. Kijów: Monastyr Ławry Pieczarskiey Kijowskiey.

Naumow, A. (1996). Wiara i historia, Kraków: Orthdruk.
Nowakowski, P. (2004). Metropolita kijowski Piotr Mohyła i jego reforma liturgiczna. W: P.

Chomik (red.) Pokazanie Cerkwie prawdziwej... Studia nad dziejami i kultura kościoła prawosławnego w Rzeczypospolitej (s.85-102). Białystok: Libra.

Olijnyk, L. (2012). Lithos Petra Mohyły u połemicznomu dyskursi perszoji połowyny XVII st. W: Probłemy Literaturoznawstwa, Kiïvs'kìpolonìstičnì studiï. t. XIX, s. 254-258. Kiïv: Unìversitet "Ukraïna".

Romanowski, A. (2018). Wschodnim pograniczem literatury polskiej. Od Średniowiecza do Oświecenia. Kraków: Universitas.

Sakowicz, K. (1642). Epanorthosis abo Perspectiwa y obiaśnienie Błędow, Herezyey y Zabobonow w Grekoruskiej Cerkwi Disunitskiey tak w Artykułach Wiary, iako w Administrowaniu Sakramentow, $y$ w inszych Obrzadkach y Ceremoniach znayduiących się. Kraków: W. Druk. Waleryana Piątkowskiego.

Sakowicz, K. (1642). Sobor Kiiowski schismaticki prze Oyca Piotra Mohile. Złożony y odprawowany Roku 1641. Poczawszy od dnia 8. Septemb: aż do dnia 18. W którym Iż wielkie Absurda, y przeciwności Wierze Świętey Katholickiey znayduia się. Kraków: W. Druk. Marcina Filipkowskiego.

Suchariewa, S. (2014). Trójkąt polemiczny: Kasjan Sakowicz - Piotr Mohyła - Pachomiusz Wojna Orański. Bibliotekarz Podlaski, 29/2014, s. 91-104. Białystok: Książnica Podlaska. 
ISSN 1508-7719

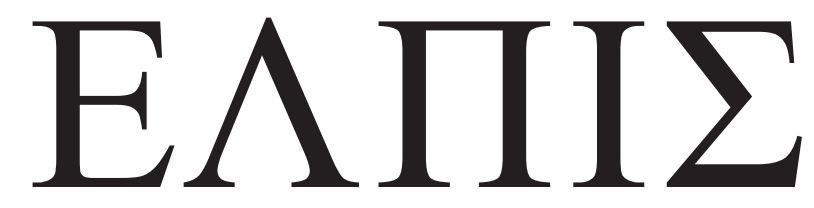

CZASOPISMO TEOLOGICZNE KATEDRY TEOLOGII PRAWOSŁAWNEJ UNIWERSYTETU W BIAŁYMSTOKU

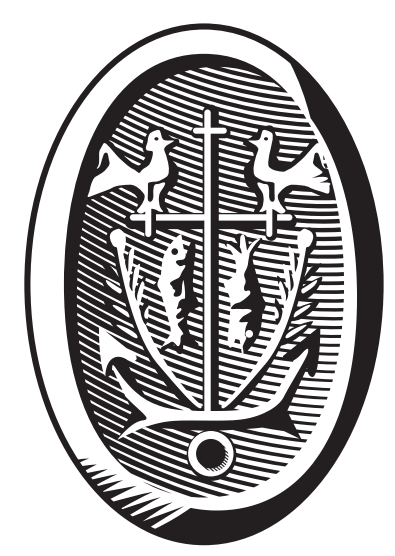

ADRES REDAKCJI

ul. Ludwika Zamenhofa 15, 15-435 Białystok, Polska tel. 85 745-77-80, e-mail: elpis@uwb.edu.pl www.elpis.uwb.edu.pl 